\title{
Rewriting the Narrative of Scripture: Twelfth-Century Debates over Reason and Theological Form
}

\author{
EILEEN SWEENEY
}

While the history of Western philosophy as a whole can be seen as the appropriation by philosophers of the discourse of truth from the poets and makers of myth, of the replacement of narrative form by the 'properly philosophical' form of argument, it is an appropriation that also takes place within medieval thought, particularly in the construction of theology as a legitimate academic discipline. ${ }^{1}$ Whether that appropriation constitutes progress or loss was as much debated in the Middle Ages as it is in recent thought.

1. Though this will receive more substance below, I note here that the standards of 'legitimacy' for the study of Scripture I am interested in here are not institutional but internal, i.e., those sacred study is measured against in order to take its place among the secular arts, in an age of increasing emphasis on these arts and increasing formality and rigor in their study and construction. Viewing twelfth-century debates in terms of the opposition between narrative and dialectical forms in theology was suggested to me by the topic of the 1989 International Association of Philosophy and Literature conference, whose subject was "Dialectic and Narrative," at which an early version of this paper was presented. I am greatly indebted to discussions with Louis Mackey concerning these twelfth-century figures. I am also indebted to Emmet Flood's “The Narrative Structure of Augustine's Confessions: Time's Quest for Eternity," International Philosophical Quarterly 28 (1988): 141-162. 
I offer this medieval chapter not to take a side on the issue, but as an example of some of the presuppositions and dangers awaiting both sides of the polemic. The particular episode I would like to examine is a well-known one, the conflicts over and changes in the nature of theology in the Latin twelfth century, beginning with the even more familiar conflict between Abelard and Bernard of Clairvaux. I offer this essay with full knowledge that characterizations of this conflict are cliché-ridden. It has been seen as the conflict between the first stirrings of the modern critical spirit and the conservative, fideistic opposition, between an emerging 'scholastic' and a revised 'monastic' theology, and/or between 'systematic' and 'mystical' theologies. ${ }^{2}$

Instead of supporting or rejecting any of these clichés, I would like to tell a different version of this familiar story, to argue for another layer of meaning embedded in the events and terms of this debate. I will, then, recast the conflict in two ways: first, by inserting a third party into the debate, Hugh of St. Victor and, second, by focusing on the account of theological form given by these three figures, more specifically on the degree to which they think theology can and should be recast in dialectical form, given the narrative form of its text, Scripture. What I shall show is that it is no accident that differences over narrative and dialectical form accompany the more well-known

2. I am thinking here specifically of Marcia Colish's recent caricature of the traditional caricatures in "Systematic Theology and Theological Renewal in the Twelfth Century," Joumal of Medieval and Renaissance Studies 18 (1988): 135-137. The history of scholarship surrounding the types and tendencies of twelfth-century theology Colish alludes to is complicated. Typical of the early twentieth century, Martin Grabmann's two-volume Die Geschichte der Scholastischen Methode (Freiburg i.B.: Herder, 1911) devotes scant attention to Bernard of Clairvaux and refers to all twelfth-century projects simply as 'pre-scholastic'. Charles Homer Haskins, in The Renaissance of the Twelfth Century (Cambridge, Mass.: Harvard University Press, 1927), helped originate the distinction between 'monastic' and 'scholastic' theology. Leclercq reassesses Haskins's claim in "The Renewal of Theology," in Renaissance and Renewal in the Twelfth Century, eds. Robert L. Benson and Giles Constable (Cambridge, Mass.: Harvard University Press, 1982), pp. 68-87, arguing for not two, but three types of theology: 'monastic', 'speculative', and 'pastoral' (the theology of the cathedral schools). As an advocate of the superiority of monastic writers, Leclercq seems to be the main object of Colish's caricature, while Colish's recent work (e.g., the article cited above) argues for the superiority and vitality of the schools and the sentence collectors. See also Leclercq's response to Colish, "Naming the Theologies of the Early Twelfth Century," forthcoming in Mediaeval Studies. 
conflict over the roles of faith and reason. Seen in this light, the medieval conflict between faith and reason becomes a version of the current conflict over philosophical form and the nature of inquiry in general, over whether inquiry is most truly represented by narrative or dialectical structures.

I use the notions of 'narrative' as opposed to 'dialectical' form at one level as a way of characterizing the traditionally assumed and articulated (though never perfectly realized) distinction between 'philosophical' and 'literary' texts, between argument and story, truthtelling and fiction, logic and rhetoric or poetry, univocal and figurative language. The indigenous version of these distinctions, articulated and placed in question in these twelfth-century discussions of theological form, is between the study of Scripture conceived as lectio as opposed to disputatio. The former is described as slow, continuous reading of Scripture, following its narrative order and interpreting 'narratively', giving multiple meanings to the text which imitate its narrative order at higher levels. The latter, however, stops Scripture's own narrative order to ask questions from another order, e.g., about consistency with other parts of the 'story' or with other interpretations and conclusions. It issues not in interpretations paralleling and retelling the stories of Scripture, but in arguments, positions, and conclusions. The goal of the lectio is a synthetic grasp of the text that is almost affective and experiential, while disputatio is analytic and critical and aimed at understanding.

Now anyone familiar with the twelfth century will recognize these sketches as caricatures, as pure forms never found in practice. Nonetheless these are, as we shall see, the terms in which the conflicts between Bernard and Abelard are cast, terms their own rhetoric pushes toward unrealized and, I will show, unrealizable extremes. What prevents the realization of these caricatured versions of narrative and dialectical theologies is that, like all discourse, theological discourse can only be practiced in time-in a time that breaks down the synthesis of the lectio before it is ever achieved, and that configures the moments, questions, objections of the disputatio into a sequenced pattern, a kind of whole.

My own 'narrative' of this chapter in the history of philosophy will be broken down into the following parts. I turn first to a variety of texts on the forms of theology, either as articulated by Abelard and Bernard, or from texts reflecting or forming their views. I will discuss, 
second, their differences over and respective emphases on the roles of faith and reason, and the relationship between this conflict and that over theological form. My 'argument' is that despite their differences over faith and reason, and over Scripture study conceived of as lectio vs. disputatio, Bernard and Abelard at their most extreme (and, I might add, at their worst) share a desire for certainty that would make theology (and philosophy) either unnecessary or impossible-Bernard because he demands a certainty of faith which makes inquiry unnecessary, Abelard because his doubt is so pervasive and irremediable that it makes inquiry impossible. Hence, they serve as an example of what Louis Mackey has called the "strange but perennial alliance between theological reaction and philosophical rationalism." 3 Third, I turn to Hugh of St. Victor's attempt to construct a theology that is both narrative and dialectical-one which, like Bernard's, is based in the tradition of lectio of Scripture, undertaken in faith and oriented toward spiritual growth, and, like Abelard's, is a rationally rigorous, speculative enterprise that begins in the doubt which makes inquiry both necessary and possible. Hugh accomplishes this rapprochement between faith and reason, narrative and dialectic, by recognizing, on the one hand, that faith as well as doubt makes inquiry possible and, on the other, that dialectical inquiry has an intrinsically narrative structure. In other words, Hugh's theology is one whose dialectic of faith seeking understanding imitates the structure of the Christian narrative of fall and redemption and reflects the predicament of the Christian as viator, as a pilgrim who is always already fallen and who is moving toward, but never quite reaching, redemption. I will end by making a very tentative suggestion about the way in which these dialectical and narrative patterns inform the structure of Peter Lombard's Sentences.

A final caveat before I begin my story/argument. It is important to note that the material I will consider is somewhat more complex than simply Bernard and Abelard's ex professo statements on the nature of theological reflection, though these are the most important dicta for my argument. I shall also consider the form of their own theological writing, though not its content on given questions or interpretations of Scripture, and I shall also consider the account of theological reflection implied in some of the texts and practices that formed

3. Louis Mackey, "On Terms and Terminations: The Dissolution of the Medieval Metaphor," Texas Quarterly (1978): 79. 
Bernard and Abelard's thinking, and against which they reacted. This is a complicated but still incomplete consideration of their authorships, and my selectiveness in choosing the material for this narrative (the necessity of selection itself illustrating the way story slides into argument and vice versa) I shall try to make convincing 'narratively' by the coherence of the story itself in the paper as a whole. But I offer here as downpayment a small attempt to justify it 'dialectically'. In this essay, I am not interested in the actual conclusions on given theological questions reached by Bernard, Abelard, or Hugh, nor with assessing their actual and direct influence on their own or succeeding generations of scholars. What I am interested in is their formation in and vision of their own enterprise, their sense of the form, nature, and purpose of theological reflection. No doubt Bernard and Abelard's practices do not reflect the extreme 'theoretical' positions they were prone to articulate, and no doubt Hugh's falls short of the synthesis it promises. In fact, with regard to Bernard and Abelard, my point in one sense is that if they are actually to engage in theological thought they must contradict their meta-theologies. This is exactly what they seem to be blind to and what constitutes the symmetry between their seemingly opposite positions. And, though it prevents them from being 'mainstream' in these articulations of and reactions to each other, it is also exactly what makes them representative of their age and beyond. The extremes to which they are prone map out a center in which, recognized or not, there must be a mixture of narrative and dialectic, faith and reason. 4

\section{BERNARD'S NARRATIVE AND ABELARD'S DIALECTIC}

Since Bernard's theology derives from the life and practices of the monastery and he is the spokesman for the 'tradition' against which Abelard reacts and which Hugh of St. Victor attempts

4. Compare Colish, "Systematic Theology," p. 156, who uses the metaphor of a current to characterize the importance of the neglected 'mainstream' of twelthcentury thought, systematic theologians who were neither the 'radical' Abelard is usually depicted to be, nor the 'reactionary' Bernard is thought to be. 
to rearticulate, I turn first to Bernard. In a very real sense, of course, Bernard has no 'theology', if by that term one means, as Abelard did, a discipline based on revelation but modeled in some ways on the liberal arts and distinct from its traditional form as the study of sacra pagina. ${ }^{5}$ The forms Bernard's reflection on Scripture takes, sermons and devotional works, obviate a theoretical consideration of the possibility and nature of theology. ${ }^{6}$ Hence, a discussion of Bernard's training and practice must take the place of a theoretical account of sacred study. Or, again to use the terms in which this discussion is couched, explicit reflection on 'method' is characteristic of dialectic's emphasis on universal and timeless perspective. By contrast, one can only tell the 'story' of Bernard's development.

William of St. Thierry's Golden Epistle gives an account of the proper steps and method for the reading of Scripture that reflects a model Bernard used and helped shape. It contrasts two forms of lectio: one, the careful and slow reading of a single text; another, the quick and scattered reading of many texts at once. The reader is admonished first that "[c]asual and varied reading (lectio), making discoveries as if by chance, does not edify but makes the spirit unstable, for that which is lightly taken in easily disappears from memory." Instead,

5. The term 'theology' was, of course, used before Abelard even within the monastic and scriptural tradition. See Jean Leclercq, "Etudes sur le vocabulaire monastique du moyen âge," Studia Anselmiana 48 (1961): 145. Alf Härdelin even argues for the appropriateness of 'theology' as a description of the monastic enterprise, which he calls "practical theology." But he describes this theology as one always aimed at spiritual experience and expressed in the language and mode of Scripture. See his "Monastiche Theologie: Eine praktische theologie vor der Scholastik," Zeitschrift für Katholische Theologie 109 (1987): 400-415. On Abelard's notion of theology as a science separate from scriptural exegesis, see J. Cottiaux, "La conception de la théologie chez Abélard," Revue d'histoire ecclésiastique 28 (1932): 269-276.

6. Jean Leclercq argues that it was the concrete and timely literary genres of the letter, history, sermon (rather than the abstract summa or uninterrupted commentary) that monastic writers preferred. See The Love of Learning and the Desire for God: A Study of Monastic Culture (New York: Fordam University Press, 1961), pp. 153-154. But there are surely counter-examples. Colish, for example, cites the 'systematic' works of two Benedictine writers, Rupert of Deutz and Honorius Augustodunensis (Colish, "Systematic Theology," pp. 138-142). Even Colish admits, however, that these writers had 'monastic' purposes in mind, either mystical contemplation or helping monks minister to the laity.

7. William of St. Thierry Epistola ad Fratres de Monte Dei (PL 184:327C). 
what is recommended is "from daily reading (quotidiana lectione) the commitment of something every day to the belly of memory, to be faithfully digested and recalled again and frequently ruminated upon." 8 The goal seems to be to conform one's spirit to that of the text, to become inured to its message and tone. This kind of reading, like all reading, is aimed at understanding, but it is the understanding of friendship rather than mere acquaintance, an understanding that results from a relationship with the text that is sympathetic rather than adversarial. The Epistle admonishes readers,

You will never enter into Paul's meaning until by careful attention to reading (lectione) him and by giving yourself to assiduous meditation you have imbibed his spirit. You will never understand (intelliges) David until by experience (experientia) you have put on the very affections of the psalms as your own. And the same with the rest. For all of Scripture, study is as distant from mere reading (lectione) as friendship from hospitality, and companionable affection from chance meeting. ${ }^{9}$

In the true kind of 'reading', understanding (intellectus) is effected by experiencing the truth of the text rather than its shortcomings. It is an understanding that grows like affection, not for separate and distinct attributes of the beloved, but for the person as a whole. The hermeneutic described here asks the reader to immerse herself in the text as a whole, not to ask questions of it, nor break it down into its parts. The moments of skepticism are repressed as one takes over the perspective and categories of the text in order to understand, or rather experience, it in its own terms.

There is every indication that this is the form Bernard's own reading took. William tells us that Bernard "read willingly and frequently in order (saepius) through the canonical Scriptures as a whole (simpliciter), for no other reason than to understand (intelligere) the very words." 10 Bernard's practice, following this model, is one of assimilation and submission to the narrative order, language, and authority of Scripture. It is an order that preserves the unity of the text as a whole and, hence, produces understanding. The texts of

8. William of St. Thierry Epistola (PL 184:327C). On rumination, see Leclercq, The Love of Learning, p. 73.

9. William of St. Thierry Epistola (PL 184:327D).

10. William of St. Thierry Sancti Bernardi: Vita et res gestae 1 (PL 185:241A-B). This work is usually referred to as Vita prima. 
Scripture and the Fathers were to be read, reread, memorized, and rewritten in every sermon. More than once Bernard stated that he did not wish to add anything to what the Fathers taught. ${ }^{11}$ His writings at least attempt to follow his remarks in the preface to De gradibus humilitati et superbiae. Bernard writes to Brother Godfrey, "if there is anything you approve of in what I have said, you will pray that I do not become proud; if, however-which I think more likely-I have produced nothing worthy of your study, I will have nothing of which to become proud." 12 Bernard, then, denies any originality, but, almost simultaneously in the retractio that opens the same work, apologizes for any that might have crept in, noting that he wrote something about the seraphim which he had neither heard nor read elsewhere. ${ }^{13}$ Thus, as it was for Augustine, redeemed language and rhetoric for Bernard are the language and rhetoric of Scripture, not the philosophers, the language of God, not the individual.

In Bernard's letters one frequent complaint about his contemporaries (most notably Abelard) is their seeking of 'novelty', of a new language to explain the mysteries contained in Scripture. For example, Bernard writes of Abelard, "He prefers [the philosophers'] innovations and his own novelties to the doctrines and faith of the Catholic Fathers," and he "introduces profane novelties of word and meaning in his discourses." 14 For Bernard, whatever difficulties might arise are not to be resolved by the importation of new categories, especially (and we will see why later) those of logic. Rather, they are resolved in terms of the structure of the discourse of Scripture itself, by becoming more immersed in the text, by opening one's mind and submitting one's will to its 'logic'. Such a hermeneutic views the nature of salvation

11. Leclercq cites a number of these passages. See Love of Learning, pp. 201-202.

12. Bernard of Clairvaux De gradibus humilitatis et superbiae in Sancti Bernardi Opera 3, ed. J. Leclercq and H. Rochaix (Rome: Cistercian Editions, 1963), p. 16.

13. Bernard of Clairvaux De gradibus (Leclerq-Rochaix 3:15).

14. Bernard of Clairvaux Epistolae, in Leclercq-Rochaix Opera 8 nos. 189, 332. The fact that, as Edward Little tells us, charges of 'novelty' were frequently made not only by Bernard in many contexts, but also by other writers, only underscores the significance of Bernard's remarks. A standard insult tells us something about an ethos and what it fears most. See Edward F. Little, "Relations between St. Bernard and Abelard before 1139," in St. Bernard of Clairvaux: Studies Commemorating the 8th Centenary of his Canonization, ed. M. Basil Pennington (Kalamazoo: Cistercian Publications, 1977), pp. 155-168. 
and its text as the unfolding of a whole rather than as analysis of something built up of atomic parts. It demands from the reader that she begin her interpretation from the stance of faith, from a kind of surrendering to the otherness of Scripture's language and structure, rather than from the reader's own perspective and questions.

Bernard was by no means incapable of disputatio, of using logical distinctions to construct arguments and resolve verbal contradictions in Scripture. He seems to doubt both the spirit in which it is undertaken and its ultimate usefulness. In De gradibus, Bernard constructs a disputation on a line of Scripture which in the retractatio to the work he confesses to misquoting. Bernard quotes Mark 13:32 as "Not even the Son of Man knows" instead of "Not even the Son knows." He then argues that Christ says, "Not even the Son of Man knows the day of judgment," to signify that his ignorance was a function of his human rather than divine nature. ${ }^{15}$ What Bernard is relying on here is the logicians' distinction between Christ's divine and human natures. The distinction is used to dissolve contradictions arising from the attribution of predicates to Christ appropriate only to his divine rather than to his human nature, or vice versa. Bernard uses this distinction between the different ways of referring to Christ to explain the passage that Christ as divine is ignorant of nothing, while as human he has human ignorance. So, his ill-fated argument goes, Christ refers to himself as "the Son of Man" referring to his human nature in which the ignorance of the day of judgment resides, leaving intact his omniscience as divine. Bernard concludes, "Hence, trying to prove a true conclusion, I constructed the whole following disputatio on what was false." 16 Bernard's retraction points out the vanity of his effort. The conclusion he wished to prove, that Christ is God and has all the attributes of divinity, including knowledge, he knew before he began. Out of desire to prove it, to show the logical distinction hidden in the text, he constructs an argument that reveals only his finitude (his less than complete memory) and the inappropriateness of humanly devised distinctions to the text.

15. Bernard De gradibus (Leclercq-Rochaix 3:15). Bernard explains the mistake as follows, "For while the text has only 'Neither the Son knows,' I, mistaken rather than deliberately erring, misremembered the letter to be sure, but not the sense: Not even,' I say, 'the Son of Man knows."'

16. Bernard De gradibus (Leclercq-Rochaix 3:15). 
While Evans calls Bernard's excursion into scholastic disputation "unfortunate," I would like to suggest that it might be for Bernard an illustration of the dangers of relying on oneself, on categories invented by us and foreign to Scripture, and of wandering away from the text of Scripture. ${ }^{17}$ Following the opening retraction of De gradibus in which Bernard lists mistakes and apologizes for innovation, the preface reflects on the perils, the ultimate paradox, of putting oneself forward as an expert on humility. Bernard writes "of fearing, on the one hand, speaking usefully of humility, but being found without it, or, on the other hand, keeping a humble silence, but being found useless." 18 Such an author is too self-conscious not at least to turn his mistakes into part of the lesson to be learned. The lesson is not rooted in his failed memory of the passage, but rather on his expectation that the text of Scripture should conform to our questions and, hence, our answers. The logicians' reduction of the text to propositions, which are true and consistent with others found elsewhere in it, imposes new categories on the text in order to solve contradictions essentially of its own making. It also breaks up its unity and disburses its message. Hence Bernard is not disparaging the search for a kind of 'logic' (in the broad sense) or coherence from the text, but rather the way in which the newness and elaborate cleverness of logical distinctions (like different referents for different names of Christ) result in the destruction of the 'logic' and coherence intrinsic to Scripture.

If Bernard recommends a reading of Scripture that begins in humble submission to mode of expression, in a kind of complete submersion into the whole, he also makes it clear that the end of such study is practical rather than theoretical. What begins with slow, careful lectio works toward and ends with prayer and meditation, with the transformation of one's character. Bernard's reading issues not in textbooks, in logically ordered summae of theology, but in sermons,

17. G. R. Evans, The Mind of Saint Bernard of Clairvaux (Oxford: Clarendon Press, 1932), p. 88. John R. Sommerfeldt cites some "happier" example of Bernard's use of disputation in his "Epistemology, Education, and Social Theory in the Thought of Bernard of Clairvaux," in St. Bernard of Clairvaux: Studies, pp. 169-179. But these examples are not drawn from discussions of speculative theological questions. They occur in contexts where Bernard is dealing with heresy or with the application of Scripture to contemporary problems.

18. Bernard De gradibus (Leclercq-Rochaix 3:16). 
in exhortations based in Scripture to the moral and spiritual life. Predictably, Bernard's main concern in his letters about the heresy in the schools such as Abelard's is not theoretical but practical, a concern for the effect of such novelties and subtleties on the faith of common people. ${ }^{19}$ Thus, Bernard keeps his eye firmly fixed on what, for him, is the only meaningful context for reading, interpretation, and argument-the enrichment of one's spirituality and commitment to the faith.

Abelard's goal is not different from this, but he certainly chooses different rhetoric and a different path to arrive there. His path lies no longer through submission to the order and language of Scripture, nor to the tradition of commentary on it, nor, perhaps most importantly, to instruction under a master. ${ }^{20}$ The master Abelard most explicitly rejected was, of course, Anselm of Laon. Though Anselm was certainly less conservative than Bernard, he is still, at least for Abelard, spokesman for the traditional method of reading and interpreting Scripture in order and from accepted authorities. ${ }^{21}$ What was novel at Laon, according to Beryl Smalley, was that this reading was both wider and less deep than elsewhere, and was interrupted for

19. See, for example, Bernard Epistolae, in Leclercq-Rochaix Opera 8, nos. 188, $338,336$.

20. For the argument that the goal of Abelard's theology, like Bernard's, is spiritual enrichment, see the next section below.

21. The School of Laon is the subject of almost as much controversy as the school of Chartres. Colish reports that Grabmann (Geschichte der Scholastichen Methode, pp. 157-168) and de Ghellinck (Le mouvement théologique de XIle siecle [Bruges: Editions "De Tempel," 1948], pp. 138-148) originally argued for the roots of a systematic science of theology at Laon. A more careful look at the texts has revealed that their 'systematic' organization is the result of later compilers. Valerie Flint, by raising questions about the filiation of these texts with Laon and Anselm, has argued that there was no 'school' at Laon at all. See her "The School of Laon: A Reconsideration," RTAM 43 (1976): 89-111. For an account of these controversies, see Marcia Colish, "Another Look at the School of Laon," ADHLMA 53 (1986): 7-13. Colish argues that the Laon masters did not make an original methodological contribution to the development of theology, either in giving it a systematic organization or in applying dialectical methods to theology. They were creative in using traditional authorities to solve contemporary problems. I am here much less concerned with assessing the facts about the school of Laon or even the accuracy of Abelard's portrayal than I am with noting the way Abelard understands his own work as a reaction to the shortcomings of Anselm and others like him. 
short and, apparently, shallow discussion of questions or problems. ${ }^{22}$ Such a compromise (like most such hybrids) could not have pleased either those looking for an opportunity to dispute or those hoping to 'taste' (sapere) the wisdom (sapientia) of Scripture fully. It surely did not please Abelard, who describes Anselm as "admirable in the eyes of an audience, but of no account in the examination of a question." Anselm, Abelard continues, "had a marvelous way of using words, but their meaning (sensum) was minimal (contemptibilem) and empty of reason (ratione)." 23 The contrast Abelard sets up here is between surface ('use') and depth (meaning), between the production of admiration from mere facility with language and understanding, words informed with a discernible meaning.

The contrast between surface and depth is one Abelard's Historia returns to repeatedly. At the Council of Soissons condemning Abelard's work on the Trinity, Abelard is both humiliated and frustrated at being forced to recite, but forbidden to explain the Athanasian Creed-after having been criticized for espousing a view for which Athanasius was the authority. ${ }^{24} \mathrm{He}$ also tells of being asked for the authority (namely Augustine) behind the claim that God did not beget Himself, but being cut off from both rational explanation and interpretation of both his own and Augustine's remarks. ${ }^{25}$ Abelard's criticism of his accusers is the same he leveled at Anselm of Laon, that they are concerned only with surface correctness rather than with inner meaning or understanding, interested in following the received form blindly rather than breaking its order and structure to question and reorder it.

Abelard's rejection of others' authority for his own is, then, simultaneously the rejection of the authority of the text's own narrative categories which Abelard translated into the language and structures of dialectic, unlike Bernard, who has been described as translating the

22. Beryl Smalley, "Some Gospel Commentaries of the Early 12th Century," RTAM 45 (1978): 149. Compare Ermenegildo Bertola, "Le critiche di Abelardo ad Anselmo di Laon e ad Guglielmo di Champeaux," Rivista della filosofia neo-scolastica 52 (1960): 495-522.

23. Peter Abelard Historia calamitatum, ed. Jacques Monfrin, 3rd ed. (Paris: J. Vrin, 1978), p. 68.

24. Abelard Historia (Monfrin 88-89).

25. Abelard Historia (Monfrin 84-85). 
'scholastic' language of correspondents back into biblical language. ${ }^{26}$ In the Historia, Abelard tells of his rejection both of Anselm's method and authority and of beginning his study of Scripture as an expert, giving a master's lecture without having studied with a master, telling his fellow students, "it was not my custom to progress by practice (usum), but by my own intelligence (ingenium)."27 Rejecting the performance of an outward act uninformed by the control, expertise, or understanding which would make it one's own, Abelard seeks to give his words the interiority Anselm and his accusers' words lack. $\mathrm{He}$ cannot follow their tracks but must make his own, must rely on his own ingenium. And what began as giving a lecture on Ezekiel before having ever been instructed by a master, continued in Abelard's other theological ventures. In them, Abelard thinks of himself as sui generis (even if he is not), as following no previously laid down pattern of questioning, form, or interpretation.

What Abelard's ingenium produced were several works in systematic theology, the first of which was the Sic et non. In a way the Sic et Non is Abelard's response to the Glossa ordinaria, in which Anselm and his school played a large role. ${ }^{28}$ The latter follows the text of Scripture, but appends to that text solutions to textual problems (both grammatical and logical), guides to whether a given passage should be taken historically or allegorically, and clear, if brief, interpretations of passages. ${ }^{29}$ The Glossa, constructed by many hands over a long period, supplements rather than supplants the tradition and its authority by adding interpretations to those of the Fathers. Thus, in the terms of

26. This is Erich Kleineidam's description of Bernard in Wissen, Wissenschaft und Theologie bei Bernhard von Clairvaux (Leipzig: St. Benno, 1955), pp. 147, 153, 156. It is repeated by Leclercq, Love of Learning, p. 201.

27. Abelard Historia (Monfrin 69).

28. On Anselm and the School of Laon's role in the construction of the Glossa Ordinaria, see Smalley, "Some Gospel Commentaries," pp. 149ff., and The Study of the Bible in the Middle Ages (Oxford: Clarendon Press, 1952), p. 60; Flint, "School of Laon," p. 92. On the construction of the Glossa more generally, see Margaret Gibson, Lanfranc of Bec (Oxford: Clarendon Press, 1978), and her "The Place of the Glossa ordinaria in Medieval Exegesis," in Ad litteram: Authoritative Texts and their Medieval Readers, ed. Mark D. Jordan and Kent Emery, Jr. (Notre Dame, Ind.: University of Notre Dame Press, 1992), pp. 5-27.

29. G. R. Evans, The Language and Logic of the Bible: The Earlier Middle Ages (Cambridge: Cambridge University Press, 1984), pp. 37-47. 
this essay, it tries to combine adherence to the narrative structure of the text with submission to the history and tradition of interpretation and emerging standards of intelligibility and academic rigor. It accomplishes the first by remaining tied to the order of Scripture, the second by starting with earlier traditions of commentary, and the third, by adding comments to address contemporary questions ranging from problems arising from minor discrepancies in the text to larger grammatical, dialectical, and historical difficulties. That the Glossa as such has no author except the tradition as a whole, is not even associated with a single or discernible group of compilers, makes it of a piece with the narrative that it reiterates. It does not break the temporal sequence or assert itself as something standing over or outside of that story, to question or reorder it. Nonetheless, its own questions and additions attempt to take into account the demands of reason and understanding, without which one cannot follow the 'story' of Scripture and salvation in any meaningful way.

Abelard seems not to have seen in this tradition and in Anselm's teaching the attempt to combine the dialectical and narrative forms. His Sic et non, in contrast to the Glossa, is in no way connected to the narrative movement of Scripture and uses authorities not to solve but to raise problems. Its collection of scriptural and patristic passages, organized around questions such as "God is three-fold and contra" and "God is not a substance and contra," breaks down the narrative order of the scriptual text and the tradition of commentary it generated. ${ }^{30}$ The Sic et non's lack of connection to Scripture does have precedents in the florilegia, collections of sayings of the Fathers. In fact, consistent with his own methods, Abelard seems to have gotten most of his knowledge from such collections, in striking contrast to Bernard, who seems to have read many patristic works entire. ${ }^{31}$ The Sic et non is

30. Peter Abelard Sic et Non, ed. Blanche B. Boyer and Richard McKeon (Chicago: University of Chicago Press, 1976-77), "Index quaestionum," p. 709, questions 6 and 9.

31. On Abelard's knowledge of the Fathers from such sources, especially the collection of Ivo of Chartres, see J. G. Sikes, Peter Abailard (London: Cambridge University Press, 1932), p. 77. On the florilegia in general see, for example, Joseph de Ghellinck, Le mouvement théologique, chapter 1. On Bernard's reading of the Fathers, especially Origen, see Evans, Mind of Saint Bernard, pp. 81-85. Leclercq reports that while there were monastic florilegia, they remained instruments of reading and meditation rather than dispute. See Leclercq, Love of Learning, pp. 182-184. 
different from the florilegia, however, in its two organizing principles, abstract questions of speculative theology and contradictions among authorities in the tradition. Thus, the Sic et non represents a departure from earlier projects because it is not tied to the order and language of Scripture. Its rhetorical effect is to displace Scripture in its narrative form from the center of sacred study and turn theology into a set of problems to be resolved dialectically rather than a set of texts to be read narratively. Abelard clearly did not intend to use the collection to undermine faith, either in the authority of Scripture or in its interpreters. Rather, he constructed it as an aid for teaching methods of interpretation and argument by which contradiction might be resolved. Nonetheless, once Scripture and the tradition is removed from the center, a gap is created that can only be filled by the reader of these texts whose task it must be to take them in their newly ordered form, as expressing contradictory views, and give to this order another new and consistent ordering.

This formal difference is reflected and justified in Abelard's long prologue to the work. Smalley's thoughtful look at its prologue connects the Sic et Non with the tradition as a broader version of Augustine's project in his Quaestiones in Heptateuchum, in which Augustine examines and tries to resolve differences among biblical translations. ${ }^{32}$ This seems to have been Abelard's intention, and, to this end, he liberally salts the introduction with quotes from Augustine on the problems and methods of interpretation. As Colish and others have remarked, the examples of and rules for the resolution of contradiction contained in Abelard's long prologue to the Sic et non are not unlike those found in Augustine's De doctrina christiana. These rules were to a large degree already in use, even by Anselm, whom Abelard criticizes as offering no reasons for his conclusions. 33

However, the quotations he selects from Augustine and others and the way he weaves them into the prologue underline his text's

According to R. W. Southern even the texts selected by 'monastic' and 'scholastic' compilers were different, reflecting their different goals. See Southern, The Making of the Middle Ages (New Haven: Yale University Press, 1953), p. 207.

32. Beryl Smalley, "Prima Clavis Sapientiae: Augustine and Abelard," in Studies in Medieval Thought and Learning From Abelard to Wyclif (London: Hambleton Press, 1981), pp. 1-8.

33. Colish, "Systematic Theology," pp. 142-143. 
preoccupation with the fallenness of language and human understanding, even the supposedly redeemed language of Scripture and the Fathers. The reader is left with a strong impression of the overwhelming odds against arriving at any correct interpretation. This stands in sharp contrast with Augustine, Abelard's putative model. Augustine, while recognizing as many difficulties of interpretation as Abelard, chooses to place them in the context of the multiplicity of possible readings consistent with the faith, revelling in the plenitude rather than, as Abelard does, the poverty of meaning. Abelard's prologue is a litany of the ways in which texts and our interpretations can fail to represent reality and their author's intentions. A text may be miscopied or misattributed to an authority, Abelard explains, may repeat opinions not held by the author, may only lay out problems rather than solutions, or may take a human rather than divine perspective in its use of language. ${ }^{34}$ Besides concentrating within these few pages the many possible ways texts and interpretations can go wrong, already noted by Augustine and others, Abelard carries the possibility of error one more step, to Scripture itself. ${ }^{35}$ Though Abelard's point is ultimately to underscore the possibility of error in the Fathers, he reaches that conclusion by noting that the human writers of Scripture, the prophets or apostles "did not remain wholly strangers to error," that they may have been mistaken in their prophecies or theology. ${ }^{36}$ So much more, Abelard counsels, must lesser authorities be evaluated critically. Although always in light of the larger context of crafting coherent answers to the questions posed, the Sic et non structures the achievement of this goal as emerging out of conflict and contradiction in the tradition, and from an attitude of doubt and self-reliance on the part of the student.

Even more radical, perhaps, than the Sic et non were Abelard's Introductio ad theologiam and Theologia Christiana. They are neither commentaries, nor collections of sententiae, nor specialized treatises on some particular aspect of Christian teaching, but rather summae

34. Abelard Sic et Non (Boyer-McKeon 91-94).

35. Abelard Sic et Non (Boyer-Mckeon 97). Evans notes that Abelard does make a substantive change to the tradition in giving up "the assumption that the divine inspiration of Scripture extends to the minutest detail of the choice of words." See G. R. Evans, Language and Logic, p. 138.

36. Abelard Sic et Non (Boyer-Mckeon 97). 
of theology organized in a way completely unconnected to the order of Scripture. ${ }^{37}$ The preface to the Introductio describes a theology based upon a logical ordering of topics; it divides theology into faith or dogma (the Trinity, Incarnation, creation, original sin), charity or moral theology (the virtues, vices, and commandments) and the sacraments. ${ }^{38}$ This is a division which, as Chenu remarks, disregards the notion that salvation history is, in fact, a history, events taking place in time, and that the text which forms its substance follows the order of this history. ${ }^{39}$ If the Sic et non disintegrates the temporal ordering of Scripture into isolated problems and questions, the Introductio goes further in giving to theology another order not even nominally drawn from its narrative form.

What is the purpose of this new, non-temporal order? It is as if Abelard was thinking of a list of things to be believed (dogma) and to be done, both through our own activity (morality) and through grace (sacraments), rather than the thinking of these as arising out of the story which is salvation history and the tradition of reflection on that history. As we shall see, Hugh also divides theology into that which is to be believed and that which is to be done, but he understands these as the aim of the different levels of meaning of Scripture. Abelard, on the other hand, thinks these matters must be reconstituted in the mind of the theologian, in a different order, in one that distinguishes the content of belief from what is to be done. Mary's pondering of the words of the annunciation in her heart for Abelard signifies that she "carefully (studiose) examined each one [i.e., word] separately (singula) and compared them with each other, seeing how closely all agreed with one another." 40 Only after the separation of topics and comparison of authorities can the crucial connection between belief and action be made, Abelard implies by following this account of Mary with the question, "who can observe the words or

37. See Constant J. Mews, "On Dating the Writings of Peter Abelard," AHDLMA 52 (1985): 73-134.

38. Peter Abelard Theologia "Scholarium" 1, ed. E. M. Buytaert and C. J. Mews, CCCM 13 (Turnhout: Brepols, 1987), pp. 317-318.

39. Cf. Marie-Dominique Chenu, Toward Understanding St. Thomas, trans. A.-M. Landry and D. Hughes (Chicago: Henry Regnery, 1964), p. 260.

40. Terence P. McLaughlin, "Abelard's Rule for Religious Women," Medieval Studies 18 (1956): 292. 
precepts of the Lord by obeying them unless he has first understood them?"41 Just as in the Historia, Abelard explains his frustrations with the old and attempts at innovation as motivated by the demands of teaching the faithful. Thus, Abelard's rejection of the traditional lectio as the form for reflection on Scripture, like Bernard's rejection of disputatio, seems to be based ultimately on pedagogical considerations; they simply place different kinds and degrees of emphasis on different moments in the pedagogical process. And it is here that we arrive at the connection between dialectic and narrative form, on the one hand, and faith and reason, on the other.

\section{FAITH AND REASON, NARRATIVE AND DIALECTIC}

It is a truism to say that in the debate between Abelard and Bernard, Abelard represents 'reason' and Bernard 'faith'. However, the debate about faith and reason is, on another level, about the conflict between the narrative and dialectical forms which theology can take. For Bernard, Abelard's attempt to organize theology logically rather than around Scripture's historical structure is an attempt to overcome the need for faith. Equally, Abelard sees his own rewriting of theology in logical terms as satisfying reason's legitimate demand for understanding what it believes. What is surprising and what qualifies the truth of the truism, however, is that both Abelard and Bernard end up denying the narrative structure of reason that should, for Bernard, mirror the narrative structure of Scripture, and which should, for Abelard, be acknowledged in the doubt and desire for understanding which is the impetus for inquiry.

I turn first to Abelard's attempt to satisfy the demand for understanding. In the prologue to the Sic et non, Abelard writes that "the first key to wisdom" is "constant questioning." 42 This questioning is valued not just as an instrument of apologetics, Beryl Smalley argues, but for its own sake, as "a mental exercise making young students

41. McLaughlin, "Rule for Religious Women," p. 292.

42. Abelard Sic et Non prologue (Boyer-Mckeon 103). 
more eager and quick-witted in the search for truth." 43 But it is more than a mere exercise. The search for truth through questioning is, for Abelard, oriented to the same goal as the repetition of and meditation on Scripture. This is made especially clear by Eileen Kearney's study of Abelard's rule for monastic life at the Paraclete. ${ }^{44}$ In it Abelard argues for the same primacy of inquiry and the search for understanding he does in the Sic et Non and other systematic texts, but it is primary, Abelard argues, because it is the necessary condition for spiritual life. Only with understanding can we pray for, teach, and do the right things. Even more, Abelard notes, if we do not seek to understand God, we cannot be united with him. "Disdain for doctrine," Abelard warns Heloise, "is the beginning of withdrawal from God." 45 Kearney argues, with convincing evidence from the text, that Abelard reshapes prophecy and meditation into forms of discursive reasoning, not in order to separate reasoning from religious practice but rather as the only way to inform the outward forms of words and practices with meaning and life. ${ }^{46}$ Thus an important theme of Abelard's complaints against Anselm of Laon in the Historia returns in this later letter to Heloise - the need to give substance to the external word and deed, to inform them with the logic and clarity that produces understanding.

In response to the emptiness of the words and lack of understanding produced by the masters of sacra pagina, Abelard began, he tells us, to examine and discuss (disserendum) "the foundation of our faith by likenesses with human reason" and to compose the treatise on the Trinity (later condemned) "for the use of students who were asking for human and philosophical reasons (rationes) on this subject, and demanded something which could be understood (intelligi) more than merely said." 47 These are mere words because they are spoken without

43. Smalley, "Prima Clavis," p. 7.

44. Eileen Kearney, "Scientia and Sapientia: Reading Sacred Scripture at the Paraclete," in From Cloister to Classroom: Monastic and Scholastic Approaches to Truth, ed. E. Rozanne Elder (Kalamazoo: Cistercian Publications, 1986), pp. 111-129.

45. McLaughlin, "Rule for Religious Women," p. 288; compare Kearney, "Scientia and Sapientia," p. 115.

46. Kearney, "Scientia and Sapientia," pp. 115-119.

47. Abelard Historia (Monfrin 82-83). The treatise is printed in CCCM 13 as Theologia "Scholarium". 
understanding, and, hence, fail to function as signs so far as they have no reference. The "human and philosophical reasons," with which Abelard proposes to replace this empty rhetoric, are new analogies to explain the nature of the Trinity and the relationship between the Persons.

Taken seriously and rigorously, however, Abelard's impatient demand for "human reasons" is a refusal to enter the world created by Scripture and the commentaries on their own terms. He will not, as William of St. Thierry advises, "imbibe the spirit" of Scripture by working slowly and meditatively toward an intimate understanding, allowing his understanding to unfold over time as its story. 48 In other words, he rejects the hermeneutic which William describes and Bernard practices, eschewing their demand for 'faith' not in Christian doctrine per se but in its text's power and clarity of signification. Instead, he demands explanation and argument to defend each and every one of its expressions before he will move on to the next. As a teacher, I can only sympathize with Anselm when I imagine the scenes which led to Abelard's description of his teacher as "of no account in the examination of a question." 49 It signifies an impatience that will not wait for understanding to unfold. What Abelard seems to demand of Anselm is the impossible, that understanding be immediate, that words carry their referents with them, that one need not accept (i.e., have 'faith' in) them as signs and begin a process of seeking out their reference and meaning. ${ }^{50}$ Thus, not only does Abelard reject the narrative form of Scripture in attempting to organize synoptically and dialectically what it covers as an unfolding revelation, he also rejects the temporality and partiality of human understanding, i.e., the necessarily narrative structure of reasoning.

What I am arguing here is that this places Abelard in an almost untenable position in regard to the narrative of reasoning and Scripture. On the one hand, Abelard's concern that the intelligence be able to

48. Compare William of St. Thierry Epistola (PL 184:327D), and the discussion of this passage above.

49. Abelard Historia (Monfrin 68).

50. Here and in the following paragraphs I am indebted to Louis Mackey's account of signs and the need for 'faith' in them argued for in Augustine's De Magistro. See his, "The Mediator Mediated: Faith and Reason in Augustine's De Magistro," Franciscan Studies 42 (1982): 135-155. 
'follow' the words of a text or teacher is a recognition of the narrativity of the learning progress-a recognition that understanding will not emerge full-blown from nothing at some mysterious point in the future, nor can it in any complete form pre-exist the learning process, but must begin somewhere. For Abelard the 'suspension of disbelief' and, hence, of questioning, required of the listener to the story of Anselm and others produces only uncomprehending repetition of the story by the listener to other listeners in turn. Instead, he opts not for a suspension of but an immersion into questioning, a tactic which breaks down the story into its elements and reformulates it in answer to these questions. In other words, Abelard attempts to restructure the process so that the moments of doubt, inquiry, and understanding are really distinct yet follow from one another, so that the outward form of reflection is once again infused with real growth and progress. On the other hand, his objections to the pedagogy of Anselm center around Anselm's failure to produce complete understanding at each and every moment, his failure, in other words, to produce a narrative whose moments are atomic and self-validating, an obvious contradiction in terms. Thus, though Abelard attempts to replace the lack of real progression, of a workable process for achieving understanding in those like Anselm, he seems to hold them to a standard which would make that progression from doubt to understanding impossible.

Abelard could not, without self-contradiction, wholly refuse to acknowledge that understanding is a temporal or narrative process. Merely to speak or write is to ask listeners and readers to wait, to let the 'story' emerge over time. But, insofar as Abelard failed to recognize this contradiction and approached this extreme, Scripture and the tradition seemed to collapse under the demands for certainty and immediacy Abelard made on it. The corpus of Abelard's own work, one could argue, shows the negative result of such an approach. His works in systematic theology, meant to address the questions raised by the collation of authorities in the Sic et non, were never finished, and even though they announce a systematic organization for theology, they never completely fill out that schema.

Abelard's work in theology has certain parallels to his more wellknown work on universals. Just as he was better at exposing the difficulties confronting realism than he was at constructing a nonnominalistic alternative, so he was better at exposing the tensions and contradictions among theological authorities than he was at 
resolving them. ${ }^{51}$ Abelard's relentless (and rigorously correct) criticisms of realism's naive 'faith' in natures they could not coherently explain are followed by his attempt to map out a middle ground between realism and nominalism which is sketchy at best. In the same way, the promise of understanding from which Abelard begins in the prologue to his introduction to theology, saying, "by doubting we come to inquire and by inquiry we perceive the truth," does not progress measurably beyond doubt and has as its main by-product the opening up of the possibility of radical skepticism. ${ }^{52}$ The desire for complete understanding at every moment before proceeding and for the complete identity of sign and signified cannot be satisfied, the latter because the space between sign and signified is what allows the sign to signify some reality other than itself, the former because for that understanding to be truly complete one cannot and would not need to proceed; understanding would be transformed into intellectus, unified and timeless intuition. Hence, it is always possible to break down the ambiguous unity of sign and signified, to divide the sequential and partial grasp of understanding.

It is, I think, exactly the possibility of ending in skepticism, of opening gaps which cannot be closed, that accounts for the viciousness of Bernard of Clairvaux's attack on Abelard. In the many letters Bernard wrote describing Abelard and his teaching, there are two recurrent and, for Bernard, connected themes, Abelard's pride and the 'novel' language he creates and embraces. The following is a typical passage from Bernard's letters:

[Abelard] transgresses the boundaries placed by our Fathers in disputing and writing about faith, the sacraments, and the Holy Trinity; he changes each thing according to his wish, adding to it or taking from it. In his books and in his works he shows himself to be a fabricator of falsehood, a cultivator of perverse dogmas, proving himself a heretic not so much in his errors but in his stubborn defense of error. He is a man who oversteps his capacity, by the wisdom of his words evacuating the virtue of the cross. He is ignorant of nothing in heaven or on earth, except himself. ${ }^{53}$

51. Abelard's critique of realism and other views on universals are to be found in Editio super Porphyrium, ed. Mario Dal Pra in Scritti di Logica (Florence: La Nuova Italia, 1969), pp. 3-42.

52. Abelard Sic et Non prologue (Boyer-McKeon 103).

53. Bernard of Clairvaux Epistolae, in Leclercq-Rochaix Opera 8, no. 193. 
The preponderance of reference to reasoning and truth is unmistakable. Bernard uses them to turn Abelard's rationalistic pretentions on their head. Abelard's creations of new analogies to explain the Trinity and new genres for theological reflection are, for Bernard, the creation of new doctrines, of falsehood. Hence, Abelard's disputes 'prove' nothing but Abelard's own error, and Abelard's 'wisdom' breaks down the 'virtue' (both the strength and moral substance) of the Christian message. In Bernard's view, Abelard's pride leads him to revel in novelty, in originality, in what is new, his own and necessarily false, rather than, like Bernard, rejecting originality for the humbler task of reiterating the words of the original, authoritative, and true text.

Further, Bernard's strong reaction to Abelard is grounded in his objection to the starting-point for Abelard's rewriting of Scripture and 'perverse dogmas', to doubt and questioning rather than faith. Abelard, Bernard writes, "sees nothing 'through a glass in a dark manner', but contemplates (intuetur) everything face to face." 54 For Bernard, Abelard's standard for understanding is immediacy, which Abelard approximates by subjecting Scripture's divine authorship to the categories of human logic, by "striving to explore with his reason what the devout mind grasps with a vigorous faith." 55 Bernard objects to what he sees as Abelard's skeptical suspension of belief which waits to assent until proof has been provided, and it is to Abelard's attitude that Bernard contrasts the immediate faith of Mary and the Good Thief: "but this one [Abelard], suspecting God, does not want to believe anything except that which has been previously discussed by means of reason." 56 Explorations with human reason of what is, for Bernard, grasped immediately by faith give rise not to a unified grasp but rather to dialectic that analyzes, distinguishes, and argues. It is a dialectical analysis that may not be able to reassemble what it has broken down, and which will not, even in principle, be able to restore it to its original state of unity and integration.

54. Bernard Epistolae, in Leclercq-Rochaix Opera 8, no. 338.

55. Bernard Epistolae, in Leclercq-Rochaix Opera 8, no. 338.

56. Bernard Epistolae, in Leclercq-Rochaix Opera 8, no. 338. Recall that for Abelard Mary is the model not of immediate and unquestioning faith, but of action and belief informed by understanding. Mary, after all, "pondered the Word in her heart." See Kearney, "Scientia and Sapientia," p. 117; McLaughlin, "Rule for Religious Women," p. 292. See the second section above, for another discussion of this passage. 
In a peculiarly apt metaphor for my analysis of his objections to Abelard, Bernard accuses Abelard of having divided and shredded the seamless tunic of Christ, a garment which, even if it could be resewn, would nonetheless be irrevocably changed. 57 "But," he continues, "the seamless tunic remains unified (integra), having been woven as a whole (contexta per totum).... What has been thus woven, what the Holy Spirit has joined together, cannot be dissolved by human beings." 58 What this tells us about Bernard is perhaps more revealing than what it tells us about Abelard. Scripture for Bernard is this seamless whole, its text and 'context' indivisible. But the wholeness and unity Bernard attributes to Scripture and to faith in its message is fictional. Its 'text' and faith in it, though woven together (contextum) in ways perhaps not reflected by Abelard's Sic et non, is nonetheless woven of distinct words, stories, and books. Bernard, no less than Abelard it seems, ultimately rejects the construction of a theology whose structure mirrors the structure of its text. With Abelard, he asks for a timeless and unified grasp of the content of revelation, but he does so as a matter of faith rather than reason.

Bernard's letters excoriating Abelard express his fear that the 'faith of the simple' will be lost through their exposure to Abelardian dialectic. Bernard clearly longs for a return to 'simple faith'. He writes, "the faith of the simple is being ridiculed, the secrets of God are being torn to pieces, questions concerning the highest things are being recklessly discussed in the open." 59 William of St. Thierry describes this simplicity as follows: "Simplicity, in fact, is properly the will fundamentally turned toward God asking of the Lord only one thing... with no ambition to multiply itself by becoming dispersed in this world." 60 Bernard and William seem to equate 'the faith of the simple' with 'simple faith' (unanalyzed, unmultiplied, immediate faith). The problem, of course, a problem that Bernard does not seem completely unaware of in his better moments, is that it is by definition impossible to return to simple faith. Faith, even if retrieved after having been doubted or lost, is never simple again but is always sophisticated and fragmented, always infected with doubt. Seams, no matter how

57. Bernard Epistolae, in Leclercq-Rochaix Opera 8, no. 334.

58. Bernard Epistolae, in Leclercq-Rochaix Opera 8, no. 334.

59. Bernard Epistolae, in Leclercq-Rochaix Opera 8, no. 188.

60. William of St. Thierry Epistola (PL 184:316C). 
neatly and closely sewn across rifts of doubt can always be pulled apart again, and they will always be points of weakness and stress in the garment. Further, and more importantly, faith which recognizes itself as faith can never completely deny the possibility of doubt. It has never been completely 'seamless'; it cannot, except through selfdeception, be immediate, whole. Bernard should have seen that just as moral reform undertaken to repair a fall from Benedict's original model of the religious life could not be a 'simple' return to this earlier innocent state, but must be a complex, imperfect return which bears the mark of the fall which made it necessary, so the intellectual repair of the fall into doubt cannot pretend to erase the traces of that doubt. Bernard's letters about Abelard seem to have forgotten this bit of wisdom; he seems to want not so much to heal the breach and respond to the doubt Abelard has created, as to have prevented it from having ever occurred, to deny the history that precedes and makes possible understanding. With Abelard, he wants to deny, albeit in a different way, the narrative character of reasoning.

Here lies the source of that 'strange allegiance' between philosophical rationalism and theological reaction I mentioned at the outset. Both demand a certainty untainted by doubt and, hence, cooperate in making reasoning and interpretation impossible. For Bernard it is impossible because any recognition of the need for reasoning is a breakdown of 'simple' faith, which cannot be submitted to the mediation and division of argument and explanation. For Abelard it is impossible because doubt and the need for reasoning, once recognized, show the inadequacy of all starting points for the production of certainty. If Abelard is unwilling to move beyond the starting point until all doubt has been answered, Bernard is unwilling to admit that a faith which is firm has been and can be doubted, and should be examined. To put this dialectical lesson in hermeneutical terms, we can say that just as Abelard denies the moment of faith in all interpretation, in which one comes to the text with a certain faith in its signification and reads on, hoping to return later with a more complete grasp, so Bernard denies the moment of doubt in the meaning of a text that begins the process of reading and interpretation by giving it a question. Using the terms of narrative, we might say that just as Abelard remains unable to move beyond the beginning of the reasoning and interpretive process, so Bernard in a sense wants to skip over beginning and middle to the end, to the certain grasp of a faith 
which does not and has not ever admitted of doubt. This is beautifully illustrated by Bernard and Abelard themselves. It is Bernard who writes, "if you are a saint, you have already understood, you know; if you are not, become one, and you will learn through your own experience."61 But it is Abelard, by contrast, who asks, "Who can observe the words or precepts of the Lord by obeying them unless he has first understood them?"62 Together their views form the two halves of the Meno paradox: if you know, you do not need to inquire; if you do not know, you cannot even begin to look for that which you seek.

\section{HUGH OF ST. VICTOR: NARRATIVE FORM AND THE NARRATIVE STRUCTURE OF FAITH SEEKING UNDERSTANDING}

Hugh of St. Victor fits into this narrative as the one who, with Socrates as against Bernard and Abelard, solves the paradox and attempts to reunite faith and understanding and assimilate theology's academic form with its narrative text. ${ }^{63}$ I will begin with the latter. Unlike Bernard, Hugh deems it necessary to ground the practice of reading and meditation on Scripture in a theoretical account of the nature of such a process. It is in this context that Hugh attempts to formulate a discipline of sacred study which will stand on a par with the artes, yet in some sense retain a form and project appropriate

61. Bernard, De consideratione ad Eugenium Papam nos. 5, 14, 30, as in LeclercqRochaix Opera 3.

62. McLaughlin, "Rule for Religious Women," p. 292.

63. Though I have chosen to recast traditional ways of categorizing Hugh in terms of dialectic and narrative, my view of Hugh is somewhere between the extremes of some early twentieth-century evaluations of Hugh as, on the one hand, "a mere mystic" with no interest in the project of seeking understanding of the things believed, and as a mere forerunner (and less perfect version) of the great scholastic tradition. The former is Barthélemy Hauréau's view in Les oeuvres de Hughues de SaintVictor (Paris: Hachette, 1886), p. 424; the latter, the view of Martin Grabmann in Geschichte der Scholastischen Methode, p. 234, and of Joseph Mariétan in Le probleme de la classification des sciences d'Aristote à Saint Thomas (Paris: Felix Alcan, 1901), p. 131. 
to Scripture, not logic. ${ }^{64}$ This is accomplished in two ways using the model of the artes. First, sacred study is given a well-defined subject, on the basis of which its text is divided into the Old and New Testaments (each given a further tripartite division). It is then subdivided into the 'disciplines' of the three levels of meaning: history, allegory, and tropology. ${ }^{65}$ Second, it is given a method of reading that moves from the letter, to the sense, to the deeper or spiritual meaning. ${ }^{66}$ What is significant about these divisions of sacred study is that they are, unlike Abelard's, at once grounded in the narrative structure of Scripture and designed to constitute a logical division of its topics or disciplines.

Let me explain. First, the subject of theology is given by Hugh as "the work of restoration," the restoration of our fallen human nature to its pre-lapsarian state, including how we came to need restoration (the fall) and the world into which we were placed (creation).67 The subject matter of Scripture is, then, the works of creation (Old Testament) and restoration (New Testament). Hugh's systematic work on theology, De sacramentis, is patterned on this description of the subject of sacred study. Thus, the subject of theology is divided temporally, into creation and restoration, mirroring the temporal structure of Scripture. Within this narrative framework and in an order suggested by its order, Hugh touches on what are normally considered the 'topics' of speculative theology, e.g., faith, doctrine, morality, the Trinity, the Incarnation. ${ }^{68}$ Similarly, the three levels of meaning of

64. Compare Marie-Dominique Chenu, Théologie au 12ème siècle (Paris: J. Vrin, 1957), p. 202.

65. Hugh of St. Victor Didascalion 5.2 and 6.2-5, ed. Charles Henry Buttimer (Washington: Catholic University of America Press, 1939), pp. 95-96 and 113-123.

66. Hugh of St. Victor Didascalicon 6.9-11 (Buttimer 126-129).

67. Hugh of St. Victor De sacramentis christianae fidei (PL 176:183A, 184A-B).

68. Compare G. R. Evans, Old Arts and New Theology (New York: Oxford University Press, 1980), p. 27, for whom Hugh's De sacramentis is an attempt to combine two approaches to theology, "the study of the Bible and that of speculative theology where Scriptural passages serve principally to pose problems or to furnish proofs for use in problem solving." See also Roger Baron's general assessment of Hugh's organization and definition of theology in Science et sagesse chez Hughues de Saint-Victor (Paris: P. Lethielleux, 1957), p. 84. For a view of some of the ways in which Hugh arguably fails to follow through on the coherent schema he has created, see Colish, "Systematic Theology," pp. 143-145. While many of these observations seem quite correct, some of Colish's criticisms of Hugh seem to measure De sacramentis against the yardstick of the Lombard's Sentences, which, I will argue below, is conformed to a different 
Scripture and the 'method' they generate have a double function: they are both logical categories and narrative structures. On the one hand, they give to theology its disciplines-dogma, things to be believed, and morality, things to be done. ${ }^{69}$ Hence, the historical and allegorical levels are the repositories of dogmatic and the tropological of moral theology. But the three levels of meaning of Scripture also ground a method of reading, a method that Hugh constructs to mirror the narrative structure of the text it attempts to interpret.

The method of reading for Hugh consists in the movement from the letter of the text, its orthographic and grammatical construction, to its sense, the literal meaning of the words, to its sententia, the inner sense or underlying meaning, the meaning, not of the words but of the things those words name. ${ }^{70}$ Hence, the sense corresponds to the historical/literal level and the sententia to the two spiritual meanings, allegory and tropology. This rather simple model of reading

model of theological reflection. Hence, Colish criticizes Hugh for not opening with an account of the divine nature and proofs for God's existence, for example. She argues that Hugh's account is hopelessly confused by beginning with the six days of creation, a discussion of prime matter, the creation of human beings and why creation occurred at all, and so on. But clearly Hugh is following the order of Scripture, which begins not with a definition of the divine nature, but with creation. Hugh seems to be attempting to take up speculative questions, such as whether there is prime matter, as they would arise in a sequential reading of Scripture. What he found out, and what Colish criticizes him for, is that the explanation of events as they occur in Scripture often requires an account of things that have not yet occurred. The account of the fall provokes Hugh into an account of the need for the Incarnation.

69. "You are given in history what God has done to admire, in allegory his sacraments to believe, in morality his perfection to imitate." Hugh of St. Victor Didascalicon 6.3 (Buttimer 113-117); compare 5.6 (104-105).

70. Hugh of St. Victor Didascalicon 6.9-11 (Buttimer 126-129). See Beryl Smalley, The Study of the Bible in the Middle Ages (Oxford: Basil Blackwell, 1957), pp. 97-106, for the view that Hugh's grounding of the other levels of meaning in the literal level constitutes an important departure from previous and contemporary traditions, for whom the spiritual meanings are more important. Compare Henri de Lubac's response to Smalley for the view that Hugh does not create such an emphasis but rather maintains it, in the tradition of Augustine and Gregory the Great. See De Lubac, Exégèse médiévale 1/2 (Lyon: Editions Montaigne, 1961), pp. 357-359. De Lubac argues that the literal and spiritual senses are not opposed for Hugh (as they tend to be in the modern mind). Rather the senses arise from "the movement of faith itself, which from simple narration [the literal level], carries itself all the way to mystery [the allegorical level]" (Exégèse médiévale, p. 359). 
is complicated by the realization that the text of Scripture, while never wrong, cannot always be taken literally. Hugh writes,

the Divine Page, according to the literal sense, contains many things which seem both to be opposed to each other and, sometimes, to imply something absurd or impossible. But the spiritual meaning (intelligentia) admits no opposition; in it many things can be diverse but none can be opposed. ${ }^{71}$

In this context, Hugh repeats Augustine's guidelines for scriptural interpretation in which the foundation and final arbiter of meaning are "the principles of faith." 72 This hermeneutic, of course, yields a structure of inquiry which is circular, i.e., in Scripture are found the things to be believed, yet they. can only be extracted when guided by some previous knowledge of the content of that faith. Hugh explains,

For in such a great sea of books and in the multiple intricacies of meanings (sententiarum) whose number and obscurity often confound the soul of the reader, the person who does not recognize briefly in advance, in every genus so to speak, some definite principle which is supported by firm faith and to which all may be referred, will scarcely be able to bring together (colligere) any single thing. ${ }^{73}$

The contrast is between the multiplicity and incoherence of words and meanings, which leaves the reader who confronts the text without a faithful grasp of the truth of Christianity as a whole, without preparation, and without teachers 'at sea', and unified understanding, an understanding 'collected' by a process which begins with some fore-understanding of the text, prepared for by teachers and grasped in faith. Hugh's notion of interpretation and reasoning, then, is grounded on the recognition that it is only through some kind of 'faith', some

71. Hugh of St. Victor Didascalicon 6.4 (Buttimer 117-122).

72. Hugh of St. Victor Didascalicon 6.4 (Buttimer 117-122). Hugh also quotes the following hermeneutic principle from Augustine, "When therefore we read the divine books, [and we meet] such a great number of true meanings (intellectuum) that are brought out from few words and built up by the soundness of Catholic faith, let us choose in the first place what it seems certain the one we are reading thought. If however it is unclear, [let us choose] surely that which the circumstances of scripture do not impede, and what conforms to sound faith. If however the circumstances cannot be thoroughly examined, at least [let us choose] what sound faith prescribes." Hugh of St. Victor Didascalicon 6.11; compare Augustine, De Genesi ad litteram 1.11.

73. Hugh of St. Victor Didascalicon 6.4 (Buttimer 117-122). 
appeal to prior though incomplete knowledge, that both the moment of doubt about the text's signification and its resolution can take place. Thus, as some recent hermeneutical theories argue, Hugh realizes that only with foreknowledge of the text can we proceed to question it, to open the conversation with it, but equally that that foreknowledge only becomes more than prejudice by being questioned and transformed by the text.

The realization that the text must be interpreted, that its signs do not carry with them their signified is the skeptical moment which, Abelard reminds us, begins inquiry. Equally, however, doubt only emerges in relation to some touchstone for truth, some belief in the meaning of the text as a whole or, at the very least, in the possibility of its signification. Hugh seems to grasp, in other words, that though the unity of belief is necessary to reach the unity that is understanding, that unity is not immediate or original; it is 'collected' by faith that moves to the text with an expectation (rather than certainty) of unity, and 'collected' by the process of understanding which weaves together what doubt has separated and distinguished. Thus, Abelard's doubt and Bernard's faith are not mutually exclusive but exactly the opposite. They make each other possible, and it is this recognition that Hugh makes the guiding principle of the method of sacred study. This principle is, of course, that of "faith seeking understanding," and for Hugh it means that one always already believes something (and so can begin, as one must, from something accepted) and has always already doubted (and so has been moved to inquiry in the first place).

Inquiry and interpretation so understood are, I think, recognized as implicitly narrative. Hugh views the process of understanding as temporally structured, as always already having begun and as working toward completion. More specifically, the dialectic of faith seeking understanding so understood mirrors the narrative of Scripture; it projects backward to the moment of creation (faith) and fall (doubt) and projects forward to redemption (complete understanding). Just as Scripture moves toward an end, a closure, the believer moves toward understanding; however, just as no narrative, including Scripture, crosses the infinite distance between temporality and eternity, no believer can pretend to achieve complete understanding. Thus, the need for faith in that closure remains, and so, then, does the need for the recognition of the still and always incomplete nature of understanding, and, equally, of the always present possibility of doubt. 
Hugh's notions of reasoning and interpretation, then, view the reader/inquirer as always temporally located, as always already in medias res. It attempts to reconnect the doubt from which Abelard begins (but hardly progresses) and the perfect certainty to which Bernard leaps by giving the 'story' a 'middle', which consists in the dialectic of doubt and inquiry, faith and understanding. Hence, for Hugh the process of inquiry, indeed of education in the broad sense, is a narrative conforming to the narrative, to salvation history, and its necessarily temporal and incomplete character is seen as another emblem and indication of our status as pilgrims in exile in this life, as in viae. Appropriately, Hugh ends his discussion of secular study with the following characterization of the three stages of education:

Still tender is the one who finds his native land sweet; already strong is he to whom every place is his homeland; but perfect is the one for whom the entire world is a place of exile. ${ }^{74}$

The process of education and growth is a process of moving from one's native land to the assimilation of new territory, a process that would not begin unless the traveler had some place from which to begin (faith) and some sense of what was beyond 'home' (doubt). Even more, Hugh's metaphor of pilgrimage reminds us, because we do not progress to a homecoming in this life but only toward a more and more profound sense of exile, it is a process that is never finished or closed, only rewritten.

\section{EPILOGUE AND CONCLUSION}

And rewritten it was. It is (again) a truism to say that Abelard's dialectic (and not Bernard's nor even Hugh's narrative) structures the theology of the next century as the Sentences of Peter Lombard and the summae of Thomas Aquinas and others become the models for the 'proper' form of theological discourse. There are many reasons which might explain this; for example, that Hugh did not execute his plan for theology as well as he laid it out, that Hugh's model for inquiry did not seem 'rigorous' enough in light

74. Hugh of St. Victor Didascalicon 3.19 (Buttimer 69). 
of the models of knowledge and inquiry embodied in the complete Aristotelian corpus. However, my interest is not to explore the reasons why Hugh's project or others like it did not succeed, but to insist that even the shift to the dialectic of the summae is still a troping, a rewriting, rather than a denial of the narrative form of Scripture and theological inquiry.

Since I can only sketch this briefly, I want to do so by taking the most well-known example for theological form and method from the twelfth century, Peter Lombard's Sentences. First, Peter structures the Sentences's consideration of subjects in a way that seems indebted to the spirit of Hugh's project, i.e., following salvation history. It moves from the examination of the Trinity (Book I), creation and the fall (Book II), to the Incarnation (Book III), ending with the sacraments and eschatology (Book IV). Thus, Peter devises a topical arrangement of theology that, like Hugh's, mirrors the biblical narrative of creation, fall, and redemption. But that structure has been reshaped in certain ways to reflect the dialectician's concern with logical and ontological rather than temporal priority. So, for example, Peter opens with an account of the Trinity instead of beginning directly with creation, and discusses the creation of angels before the work of the six days. Moreover, the accounts of the human being and Christ are tied to a series of abstract questions organized around their 'natures' and possibilities, rather than linked to the order of Scripture, which displays these natures by telling their story. The very generalized pattern of salvation history which remains, God-creationIncarnation-sacraments-eschatology, gives its subject matter logical coherence, but also moves Peter's text away from the specific and complex narrative of Scripture and closer to dialectic.

If the ordering of topics in the Sentences retains traces of Scripture's narrative, so too does its way of confronting these various topics in its distinctions and questions. Contradictory authorities and arguments like those collected in Abelard's Sic et non are incorporated into the text and so made part of the process of inquiry. The opposing views imply a history and context for reasoning and the response moves forward toward resolution, thus inscribing on the inquiry itself its temporal character. Moreover, the authorities expressing opposing views are not chosen for the sake of their opposition, because not all subjects are turned into a question on which opposing sides are lined up; rather, Peter sometimes seems content to state what he 
takes as an accepted view and to cite an appropriate authority to back him up. In Colish's view, Peter is not merely selective but is judicious in his use of authorities. ${ }^{75}$ Even if this is not always the case, as Colish also remarks, "Peter treats theological debate as a normal mode of theological investigation."76 I would add, however, that he places that debate carefully within a tradition of past wisdom rather than confusion, and gives a model for a resolution of its conflicts in his own present and provisional solutions. Moreover, Peter's theology is also, like Hugh's, oriented toward a future in which it will be superceded. Though Peter's answers sometimes seem a little too pat and unspeculative, the tradition of commentaries on his Sentences certainly tended toward the opposite of both of these, i.e., neither simple nor narrow solutions, and Peter himself must be seen as playing some role in what became of his work, in its continual revision and reinterpretation by masters of theology for many generations. Peter's remark at the end of one question he has solved, "if anyone can do better, I am not envious," is perhaps emblematic of his vision of his own work, as not only at the head of a long, illustrious tradition preceding him but also at the tail of a tradition he knew would and should bypass him. ${ }^{77}$ Thus Peter's text, like Hugh's, reenacts the narrative of Scripture, creation, fall, and movement toward salvation. It does so by replacing the kinds of disputed questions Abelard and others were asking, which have a tendency to dissolve the narrative line both of inquiry and of salvation, into the narrative out of which they arise, a tradition that articulates what is to be believed, that raises doubt, and that moves toward full understanding.

Hence, the narrative character of inquiry has been rewritten rather than completely erased insofar as Peter aims at harmonizing various authorities and evidence in light of a past tradition of inquiry and in terms of the larger narrative of creation, incarnation, and last judgment mapped out by the four books. This structure serves as the ruling interpretive principle for the issues and problems which arise dialectically, and these problems are provisionally resolved by

75. Colish, "Systematic Theology," p. 152.

76. Colish, "Systematic Theology," p. 152.

77. Peter Lombard Sent. 4.5.3 (CSB 3:76). This remark is noted by Elizabeth Rogers in Peter Lombard and the Sacramental System (New York: Richwood, 1976), p. 64 . 
dissolving division and opposition, so that the Sentences's overall narrative is repeated microcosmically in the structure of each topic, which reintegrate the fragmented tradition into a kind of provisional unity. Thus Abelard's dialectic becomes in the Sentences a true dialectic, one with 'narrative' features, with a form which mirrors dialectic's temporal character.

What has changed in moving from Hugh's De sacramentis to the Sentences is the nature and degree of reflection of the narrative character of understanding. While Hugh explains inquiry as a process of interpreting a text, the Lombard's questions and responses make of inquiry the solution to a problem. Textual interpretation more clearly moves from 'faith', because of its clearer reliance on the interpretive principles and foreknowledge we bring to the text, and more obviously moves toward, but never pretends to reach, complete understanding, since interpretation does not aim at the reaching of a conclusion tout court but the seeing of the parts in light of the whole and vice versa, a process which is ongoing. Disputation, even within a tradition, though recognizing the two conditions of the possibility of inquiry (doubt and faith), still tends to emphasize doubt over faith, and can be more easily read as achieving closure rather than only provisional understanding.

There are surely other equally thoroughgoing and persuasive attempts which resolve somewhat differently the tensions between narrative and dialectic, faith and reason in the twelfth and thirteenth centuries. But Peter's 'success' is instructive because it is almost too complete. The Sentences's form and 'method', because so formalized and indirectly related to its textual narrative and the narrative structure of reasoning, make it easy to forget their roots. They make it easy, in other words, to suppress the narrative moments in dialectic, the literary quality of theological and philosophical reflection. 